\title{
Respon Siswa SD dengan Kemampuan Matematika Rendah Dalam Menyelesaikan Masalah Probabilitas
}

\author{
Rahmawati Nur Aini ${ }^{1}$, Dwi Juniati ${ }^{2}$, Pradnyo Wijayanti ${ }^{3}$ \\ ${ }_{1}$ Pascasarjana, Universitas Negeri Surabaya, Surabaya, Indonesia; \\ *rahmawatinuraini20@gmail.com1 \\ ${ }^{2}$ Pascasarjana, Universitas Negeri Surabaya, Surabaya, Indonesia; \\ dwi juniati@yahoo.com \\ 3 Pascasarjana, Universitas Negeri Surabaya, Surabaya, Indonesia; \\ pradnyowijayanti@unesa.ac.id
}

\begin{abstract}
Abstrak. Tujuan dari penelitian adalah untuk mengetahui respon siswa dengan kemampuan matematika rendah dalam masalah probabilitas. Penelitian ini merupakan penelitian kualitatif dengan teknik pengumpulan data menggunakan tes dan wawancara. Teknik pengambilan sample menggunakan purposive sampling. Analisis data yang digunakan dalam penelitian ini adalah reduksi data, penyajian data, dan penarikan kesimpulan. Validitas data menggunakan triangulasi waktu. Berdasarkan hasil penelitian menunjukkan siswa dengan kemampuan matematika rendah memiliki respon terhadap probabilitas ruang sample non-statistis dan menunjukkan respon yang statistis pada probabilitas suatu kejadian serta pada perbandingan probabilitas, anak memiliki respon yang non-statistis.
\end{abstract}

Kata Kunci: Respon, Kemampuan Matematika, Masalah Probabilitas.

\begin{abstract}
The purpose of this study was to determine the responses of students with low math abilities in probability problems. This research is a qualitative research with data collection techniques using tests and interviews. The sampling technique used purposive sampling. Data analysis used in this research is data reduction, data presentation, and conclusion drawing. The data validity used time triangulation. Based on the results of the study, it shows that students with low math abilities have a response to the probability of a non-statistical sample space and show a statistical response to the probability of an event and to a probability comparison, the child has a non-statistical response.
\end{abstract}

Keywords: Response, Mathematical Ability, Probability Problems.

\section{Pendahuluan}

Diperlukan sebuah pertimbangan yang matang untuk mengambil keputusan dalam menghadapi situasi yang akan datang. Ketika melakukan pertimbangan, maka siswa dikatakan berpikir. Sebuah situasi yang di dalamnya memuat unsur ketidakpastian disebut situasi probabilistik (Sari, Budayasa, \& Juniati, 2018b). Dalam menghadapi permasalahan yang akan 
terjadi tidak cukup hanya memiliki kemampuan berpikir deterministik, melainkan harus memiliki kemampuan berpikir probabilistik (Sari, Budayasa, \& Juniati, 2018a). Tingkatan berpikir dalam menghadapi situasi probabilistik berbeda, yang kemudian disebut sebagai level pemikiran probabilistik (Kurniasih \& Sujadi, 2017).

Pemikiran probabilistik merupakan aksi pikiran yang berhubungan dengan sebab-akibat dan ketidakpastian. Setiap siswa memiliki pemikiran yang berbeda-beda sesuai dengan tingkatan pemikirannya. Hal tersebut dapat dilihat melalui respon siswa dalam memikirkan sebuah masalah (Sharma, 2014). Bentuk respon bermacam-macam, bisa berupa penggunaan ungkapan dan istilah (representasi verbal) yang berhubungan dengan probabilitas, seperti: mungkin, jarang, paling mudah, sama, lebih besar, terbesar, terkecil, lebih banyak, lebih sedikit (Ortiz, Cañizares, Batanero, \& Serrano, 2002). Ada juga yang menggunakan gambar dan diagram (representasi grafik) serta angka (representasi numerik) (Way, 2003). Bentuk repon lainnya berupa strategi yang digunakan dalam menyelesaikan permasalahan dikelompokkan menjadi empat kategori yaitu beliefs as a source for justification, subjective estimations of the compound event, chance estimations, dan theoretical calculations of the compound event (Jan \& Amit, 2009). Respon dibagi menjadi empat kategori yaitu non-response, non-statistical response, partialsattistical response dan statistical response (Sharma, 2012).

Siswa dengan kemampuan berpikir matematika tinggi memiliki respon berbeda untuk menyelesaikan masalah ruang sampel dan peluang suatu kejadian, sedangkan siswa dengan kemampuan berpikir matematika rendah juga memiliki respon yang berbeda untuk menyelesaikan masalah ruang sampel dan peluang suatu kejadian (Ivayana Sari, 2015a, 2015b). Tingkat pemikiran yang berbeda menyebabkan respon yang diberikan juga berbedabeda sesuai dengan kemampuan siswa. Kemampuan matematika merupakan satu dari beberapa hal yang bisa dilihat dalam menyelesaikan masalah probabilitas (Maher \& Ahluwalia, 2014). Selain itu perbedaan gender juga berpengaruh terhadap pemikiran probabilistik. Anak laki-laki cenderung berpikir probabilistik tinggi dibandingkan perempuan (Sari, Budayasa, \& Juniati, 2017). Hasil berbeda ditunjukkan oleh penelitian lain, perbedaan kemampuan yang diikuti dengan perbedaan media pembelajaran memberikan hasil akhir yang berbeda. Pada saat ini pembelajaran lebih

Copyright $@ 2021$

Buana Matematika :

Jurnal Ilmiah Matematika dan Pendidikan Matematika

p-ISSN : 2088-3021

e-ISSN : 2598-8077 
efektif dengan media berbasis aplikasi dibandingkan media konvensional atau buku (Sujadi, Kurniasih, \& Subanti, 2017).

Hasil penelitian yang ada menunjukkan adanya gap terutama pada siswa yang memiliki kemampuan matematika rendah. Perbedaan ini dapat menunjukkan bahwa adanya perbedaan daya serap dan respons dari siswa ditinjau dari kemampuan matematika. Oleh karena itu, Tujuan penelitian ini untuk melengkapi dan memberikan informasi tambahan bagaimana respon siswa dalam menyelesaikan masalah probabilitas dimana fokus penelitian ini pada siswa yang memiliki kemampuan matematika rendah. Penelitian ini diharapkan bisa memberi informasi bagi tenaga pendidik khususnya bagaimana respon siswa dalam menyelesaikan masalah probabilitas untuk merancang pembelajaran yang berkaitan dengan masalah probabilitas yang berfokus pada siswa dengan kemampuan matematika rendah.

\section{Metode}

Penelitian ini menggunakan pendekatan kualitatatif. Penelitian kualitatif merupakan penelitian yang mendalami suatu peristiwa, gejala, fakta, kejadian, realita, atau masalah tertentu (Raco, 2018). Tujuan penelitian ini adalah memahami kondisi dengan mengarahkan pada analisis deskripsi secara rinci dan mendalam tentang konteks yang natural (Nugrahani \& Hum, 2014). Purposive sampling digunakan dalam pemilihan subjek penelitian, anak pada usia 11 sampai 12 tahun atau setara kelas lima Sekolah Dasar dipilih didasarkan pada teori perkembangan kognitif piaget's dimana pada usia tersebut memiliki pemikiran dan proses probabilitas (Feldman, 2004). Purposive sampling tidak memperhitungkan jumlah sample, tetapi lebih kepada pemilihan sumber informasi yang bertujuan mendapatkan keberagaman data yang lebih lengkap dan representatif (Nugrahani \& Hum, 2014).

Dalam memilih subjek penelitian, siswa diberi soal tes kemampuan matematika (TKM) kemudian dikategorikan berdasarkan pedoman penilaian pada tabel 1, untuk indikator respons pada tabel 2. Selain menggunakan nilai hasil TKM, pemilihan subjek dikonsultasikan pada wali kelas untuk memperoleh siswa yang memiliki kemampuan komunikasi baik secara tulis dan lisan. Hal ini dilakukan guna mempermudah peneliti untuk melakukan analisis lebih mendalam, karena instrumen utama pada penelitian kualitatif adalah peneliti itu sendiri (Nugrahani \& Hum, 2014). Siswa yang terpilih kemudian diberi soal penyelesaian masalah (SPM) yang bertujuan untuk melihat respons siswa dalam menyelesaikan masalah probabilitas. Soal

Copyright $@ 2021$

Buana Matematika :

Jurnal Ilmiah Matematika dan Pendidikan Matematika 
terdiri dari tiga aspek yaitu ruang sampel, probabilitas suatu kejadian, dan perbandingan probabilitas. SPM diberikan sebanyak dua kali dalam waktu yang berbeda. Hal tersebut dilakukan guna menggali informasi yang lebih dalam dan melihat konsistensi data yang diperoleh.

Tabel 1. Kategori Pengelompokan Kemampuan Matematika

\begin{tabular}{|l|l|}
\hline Nilai & Kelompok \\
\hline $80 \leq$ skor $\leq 100$ & Tinggi \\
\hline $60 \leq$ skor $<80$ & Sedang \\
\hline $0 \leq$ skor $<60$ & Rendah \\
\hline
\end{tabular}

Tabel 2. Indikator Respons dalam Menyelesaikan Masalah Probabilitas

\begin{tabular}{|c|c|c|c|}
\hline & Respons Non Statistis & $\begin{array}{c}\text { Respons Statistis } \\
\text { Parsial }\end{array}$ & Respons Statistis \\
\hline & $\begin{array}{l}\text { - } \text { memberikan } \\
\text { penjelasan dalam } \\
\text { pengambilan } \\
\text { keputusan dengan } \\
\text { estimasi subjektif, } \\
\text { yaitu berdasarkan } \\
\text { pengalaman sehari- } \\
\text { hari; } \\
\text { - membaca soal } \\
\text { berulang-ulang } \\
\text { karena terdapat } \\
\text { masalah dengan } \\
\text { bahasa; } \\
\text { - memberikan } \\
\text { penjelasan dalam } \\
\text { pengambilan } \\
\text { keputusan } \\
\text { berdasarkan } \\
\text { keyakinan estimasi } \\
\text { yang digunakan. }\end{array}$ & $\begin{array}{l}\text { - memberikan } \\
\text { penjelasan dalam } \\
\text { pengambilan } \\
\text { keputusan dengan } \\
\text { estimasi subjektif, } \\
\text { yaitu mengadaptasi } \\
\text { aturan atau } \\
\text { menerapkannya } \\
\text { tetapi tidak tepat, } \\
\text { mengacu pada } \\
\text { pendekatan hasil, } \\
\text { dan tidak cukup } \\
\text { bisa menjelaskan } \\
\text { alasan; } \\
\text { - memberikan } \\
\text { penjelasan dalam } \\
\text { pengambilan } \\
\text { keputusan } \\
\text { berdasarkan } \\
\text { keyakinan estimasi } \\
\text { yang digunakan. }\end{array}$ & 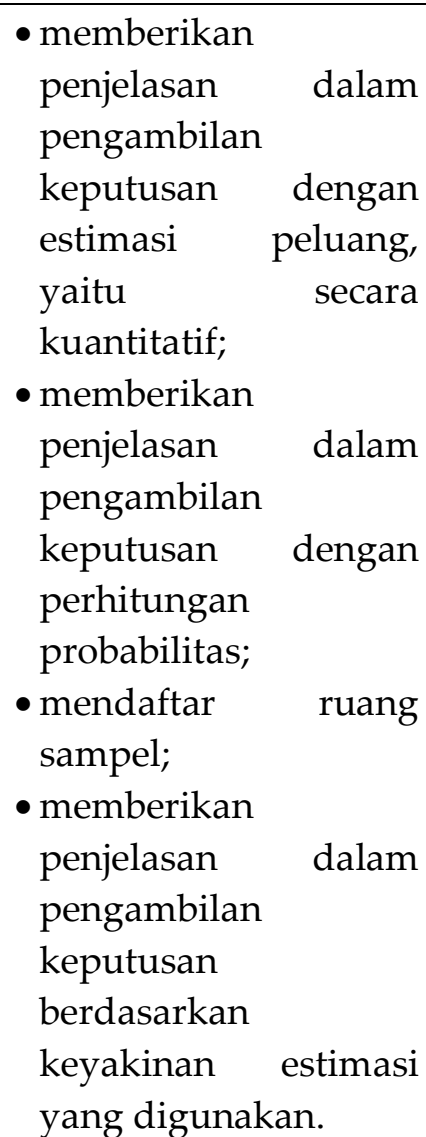 \\
\hline
\end{tabular}




\begin{tabular}{|c|c|c|c|}
\hline & Respons Non Statistis & $\begin{array}{c}\text { Respons Statistis } \\
\text { Parsial }\end{array}$ & Respons Statistis \\
\hline 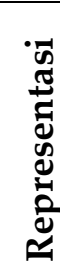 & \multicolumn{3}{|c|}{$\begin{array}{l}\text { - menggunakan ungkapan dan istilah (representasi verbal) yang } \\
\text { berhubungan dengan probabilitas, seperti : mungkin, jarang paling } \\
\text { mudah, sama, lebih besar, terbesar, terkecil, lebih banyak, lebih sedikit; } \\
\text { - menggunakan gambar dan diagram (representasi grafik), serta angka } \\
\text { (representasi numerik). }\end{array}$} \\
\hline
\end{tabular}

Teknik pengumpulan data pada penelitian ini menggunakan tes tulis dan wawancara. Tes tulis berupa TKM dan SPM. Metode wawancara yang digunakan adalah wawancara bebas terpimpin, yang artinya peneliti memiliki daftar pertanyaan dan pertanyaan tersebut dapat berkembang sesuai dengan keadaan saat proses wawancara. Instrument utama adalah peneliti sendiri. Sedangkan instrument pendukung adalah soal TKM dan soal SPM. Untuk mendapatkan data yang akurat dan tidak ada informasi yang terlewatkan, maka peneliti menggunakan alat perekam audiovisual sehingga bisa diputar kembali.

Dalam menentukan validitas data penelitian, peneliti menggunakan triangulasi waktu, untuk membandingkan dan mengecek baik derajat kepercayaan informasi yang diperoleh melalui waktu yang berbeda (Sugiyono, 2013). Teknik analisis data yang digunakan berdasarkan Miles \& Huberman, yaitu reduksi data, penyajian data, dan penarikan kesimpulan/verifikasi (Nugrahani \& Hum, 2014).

\section{Hasil dan Pembahasan}

Penelitian dilakukan di SD Khadijah Surabaya, dari jumlah 33 siswa kelas lima diperoleh enam siswa dengan kemampuan matematika tinggi, empat belas siswa dengan kemampuan matematika sedang, dan tiga belas siswa dengan kemampuan matematika rendah. Dipilih satu subjek dengan kemampuan rendah untuk diberikan SPM1 dan SPM2 dalam kurun waktu yang berbeda. Setelah itu dilakukan wawancara untuk mendalami jawaban dari subjek penelitian. Hasil penelitian kemudian direduksi disesuaikan dengan tujuan penelitian. 
Tabel 3. Hasil Reduksi Data Penelitian Berdasarkan Soal Pemecahan Masalah Ruang Sampel

\begin{tabular}{|c|c|c|}
\hline \multirow{2}{*}{ Respons } & \multicolumn{2}{|c|}{ Ruang Sampel } \\
\hline & SPM1 & SPM2 \\
\hline Strategi & $\begin{array}{l}\text { Setelah membaca soal, pada awalnya S3 } \\
\text { bingung, kemudian dia membaca soal } \\
\text { berulang-ulang sehingga memahami } \\
\text { maksud soal dan menentukan jawaban. S3 } \\
\text { menjawab mata dadu yang muncul jika } \\
\text { melambungkan dadu sekali adalah } 6 \text {. } \\
\text { Siswa memberi alasan bahwa karena } \\
\text { melempar 6, karena dadu itu nomer 6, lalu } \\
\text { dilambungkan 6, yang muncul angka } 6 \\
\text { (S311S08, S311S09). Selain itu siswa } \\
\text { menjelaskan bahwa ketika bermain } \\
\text { monopoli (S311S17), dadu yang muncul } \\
\text { kadang } 6 \text { kadang } 4 \text { (S311S19). Peneliti } \\
\text { menggali lebih dalam dengan menanyakan } \\
\text { kembali, siswa sempat menjawab mata } \\
\text { dadu yang muncul kadang 1, 2, 3, 4, 5, } 6 \\
\text { (S311S13, S311S15). Namun setelah di akhir } \\
\text { kesimpulan, siswa kembali pada jawaban } \\
\text { awal bahwa mata dadu yang muncul } \\
\text { adalah } 6 \text { karena biasanya mendapat } 6 \text { dan } \\
\text { yang lain kadang-kadang (S311S22). Siswa } \\
\text { juga mendaftar sebagian ruang sampel. }\end{array}$ & $\begin{array}{l}\text { S3 menjawab nomer undian yang bisa } \\
\text { terambil adalah nomer } 5 \text { (S321S07). } \\
\text { Siswa menjelaskan karena angkanya } 1 \\
\text { sampai 8, maka dilan mengambil } \\
\text { angka 5, seperti memilih nomer } \\
\text { (S321S08). Ketika digali lebih dalam, } \\
\text { siswa menyatakan bahwa nomer yang } \\
\text { lain kadang-kadang, dan nomer } 5 \text { yang } \\
\text { terambil (S321S13). Selain itu siswa } \\
\text { menjelaskan mengambil nomer } 5 \\
\text { karena saat memilih undian dapat } \\
\text { nomer } 5 \text { (S321S14), sesuai dengan } \\
\text { pengalaman saat dibagi nomer undian } \\
\text { (S321S15). Siswa juga mendaftar } \\
\text { sebagian ruang sampel. }\end{array}$ \\
\hline Representasi & $\begin{array}{l}\text { S3 menggunakan istilah verbal yang } \\
\text { berhubungan dengan probabilitas kadang- } \\
\text { kadang (S311S12, S311S14, S311S18, } \\
\text { S311S19, S311S21) serta menggunakan } \\
\text { angka } 6 \text { untuk menunjukkan jawabannya. }\end{array}$ & $\begin{array}{l}\text { S3 menggunakan istilah verbal yang } \\
\text { berhubungan dengan probabilitas } \\
\text { seperti kadang (S321S13) serta } \\
\text { menggunakan angka 5 untuk } \\
\text { menunjukkan jawabannya. }\end{array}$ \\
\hline
\end{tabular}

Masalah ruang sampel dapat dilihat berdasarkan tabel 3. Ketika menyelesaikan masalah probabilitas yang berhubungan dengan ruang sampel, siswa cenderung memberikan penjelasan menggunakan estimasi subjektif dan berdasar keyakinan pengalaman sehari-hari serta mendaftar sebagian ruang sampel. Selain itu siswa juga mengalami kesulitan bahasa dalam memahami soal. Saat menentukan mata dadu apa saja yang muncul jika dadu dilempar sekali, siswa menjawab berdasarkan pengalamannya saat bermain monopoli. Saat menentukan nomer undian yang diperoleh, subjek menjawab karena biasanya mendapat nomer tersebut saat dibagi undian, sehingga dapat dikatan bahwa respons siswa tergolong respons non statistis. Hal ini sesuai dengan (Sharma, 2012), yang menjelaskan bahwa hasil Copyright $@ 2021$

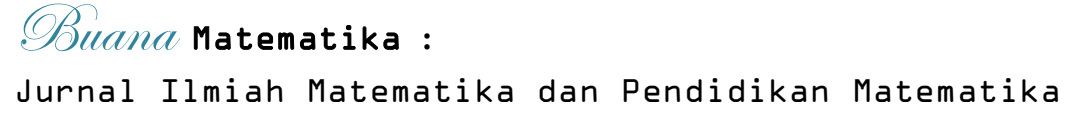


pemikiran siswa dipengaruhi oleh pengalaman sehari-hari. Dibandingkan dengan penelitian (Ivayana Sari, 2015a), bahwa siswa dengan kemampuan matematika rendah pada tugas ruang sampel dengan eksperimen memberi respon statistik, namun pada tugas berbentuk soal cerita memberi respon non-statistik. Representasi siswa dalam menyelesaikan masalah probabilitas yang berhubungan dengan ruang sampel adalah mendaftar jawaban yang diberikan dan menggunakan istilah yang berhubungan dengan probabilitas seperti lebih sering muncul, kadang, dan lebih mudah, serta menggunakan angka untuk menyebutkan jawabannya.

Tabel 4. Hasil Reduksi Data Penelitian Berdasarkan Soal Pemecahan Masalah Probabilitas Suatu Kejadian

\begin{tabular}{|c|c|c|}
\hline \multirow{2}{*}{ Respons } & \multicolumn{2}{|c|}{ Probabilitas Suatu Kejadian } \\
\hline & SPM1 & SPM2 \\
\hline Strategi & $\begin{array}{l}\text { Setelah membaca soal, S3 langsung } \\
\text { berpikir kelereng warna hijau (S312S06). } \\
\text { Siswa menjabarkan kembali isi dalam } \\
\text { kantong berwarna hitam dan } \\
\text { menyebutkan jumlah kelereng pada tiap } \\
\text { warna, kemudian memutuskan bahwa } \\
\text { ferdi mengambil warna hiaju karena lebih } \\
\text { banyak daripada yang lain (S312S06). } \\
\text { Kemudian siswa menjawab kelereng yang } \\
\text { paling mudah diperoleh adalah warna } \\
\text { hijau (S312S06). Siswa menjelaskan bahwa } \\
\text { kelereng warna hijau lebih banyak } \\
\text { daripada yang lain (S312S07, S312S08). }\end{array}$ & $\begin{array}{l}\text { Setelah membaca soal, yang dipikirkan } \\
\text { S3 adalah permen yang mudah } \\
\text { diperoleh. Kemudian memutuskan } \\
\text { permen yang paling mudah diperoleh } \\
\text { adalah permen rasa vanila (S322S06) } \\
\text { karena jumlahnya lebih banyak } \\
\text { daripada yang lain (S322S07). }\end{array}$ \\
\hline Representasi & $\begin{array}{l}\text { S3 menggunakan istilah verbal yang } \\
\text { berhubungan dengan probabilitas seperti } \\
\text { paling banyak (S312S07) dan lebih banyak } \\
\text { (S312S08). }\end{array}$ & $\begin{array}{l}\text { S3 menggunakan istilah verbal yang } \\
\text { berhubungan dengan probabilitas } \\
\text { seperti lebih banyak (S322S07, } \\
\text { S322S12). }\end{array}$ \\
\hline
\end{tabular}

Masalah probabilitas suatu kejadian disajikan pada tabel 4, dapat kita ketahui bahwa ketika menyelesaikan masalah probabilitas yang berhubungan dengan probabilitas suatu kejadian, siswa cenderung menggunakan estimasi peluang, memberikan alasan secara kuantitatif yaitu dengan membandingkan jumlah kelereng dan permen pada tiap warna dan rasa, sehingga dapat dikatan bahwa respons siswa tergolong respons statistis. Dibandingkan dengan penelitian (Ivayana Sari, 2015a), bahwa siswa dengan kemampuan matematika rendah pada tugas probabilitas suatu kejadian dengan eksperimen memberi respon statistik parsial, namun pada tugas berbentuk soal cerita, siswa memberi respon dengan membandingkan

Copyright (C) 2021

Ouana Matematika :

Jurnal Ilmiah Matematika dan Pendidikan Matematika 
besarnya suatu kejadian dengan kejadian yang lain. Representasi siswa dalam menyelesaikan masalah probabilitas yang berhubungan dengan probabilitas suatu kejadian adalah menggunakan istilah verbal yang berhubungan dengan probabilitas seperti lebih sering muncul, mungkin, paling banyak, lebih banyak, lebih mudah, dan paling mudah.

Tabel 5. Hasil Reduksi Data Penelitian Berdasarkan Soal Pemecahan Masalah Perbandingan Probabilitas

\begin{tabular}{|c|c|c|}
\hline \multirow{2}{*}{ Respons } & \multicolumn{2}{|c|}{ Perbandingan Probabilitas } \\
\hline & SPM1 & SPM2 \\
\hline Strategi & $\begin{array}{l}\text { Setelah membaca soal, yang terpikir oleh } \\
\text { S3 adalah keranjang B, sehingga siswa } \\
\text { menjawab keranjang B (S313S07), karena } \\
\text { telur ayamnya lebih banyak (S313S08). } \\
\text { Selain itu siswa juga membandingkan } \\
\text { jumlah telur ayam antar keranjang, telur } \\
\text { ayamnya lebih banyak di keranjang B } \\
\text { daripada di keranjang A (S313S09). Siswa } \\
\text { menjelaskan bahwa di keranjang A tidak } \\
\text { mudah diperoleh karena telur ayamnya } \\
\text { lebih sedikit (S313S11). Di akhir } \\
\text { kesimpulan siswa menjawab keranjang B, } \\
\text { karena telur ayamnya lebih banyak } \\
\text { (S313S13). }\end{array}$ & $\begin{array}{l}\text { Setelah membaca soal, yang terlintas di } \\
\text { pikiran S3 adalah keranjang A, } \\
\text { sehingga siswa menjawab keranjang A } \\
\text { (S323S06). Siswa membandingkan } \\
\text { jumlah bola tennis antar keranjang, } \\
\text { bola tennis lebih banyak di keranjang } \\
\text { A, dengan menyebutkan jumlah bola } \\
\text { tennis (ampat) dan bola baseball (tiga) } \\
\text { (S323S08). Siswa menjelaskan bahwa } \\
\text { bisa juga mengambil bola tennis di } \\
\text { keranjang B (S323S09), namun lebih } \\
\text { mudah di keranjang A daripada di } \\
\text { keranjang B (S323S10), karena bola } \\
\text { tennisnya lebih banyak (S323S11). }\end{array}$ \\
\hline Representasi & $\begin{array}{l}\text { S3 menggunakan istilah } \\
\text { berhubungan dengan probabilitas seperti } \\
\text { lebih mudah (S313S07), lebih banyak } \\
\text { (S313S07, S313S09, S313S12), dan lebih } \\
\text { sedikit (S313S11). }\end{array}$ & $\begin{array}{l}\text { S3 menggunakan istilah verbal yang } \\
\text { berhubungan dengan probabilitas } \\
\text { seperti lebih banyak (S323S07, S323S11) } \\
\text { dan lebih mudah (S323S09, S323S10). }\end{array}$ \\
\hline
\end{tabular}

Masalah perbandingan probabilitas ditampilkan pada tabel 5. Ketika menyelesaikan masalah probabilitas yang berhubungan dengan perbandingan probabilitas, siswa cenderung menggunakan estimasi subjektif, memberikan alasan secara kuantitatif yaitu dengan membandingkan jumlah telur ayam antar keranjang dan membandingkan jumlah bola tennis antar keranjang, namun tidak memerhatikan jumlah telur dan bola yang lain, sehingga dapat dikatan bahwa respons siswa tergolong respons non statistis. Representasi siswa dalam menyelesaikan masalah probabilitas yang berhubungan dengan perbandingan probabilitas adalah menggunakan istilah verbhal yang berhubungan dengan probabilitas seperti lebih sedikit, lebih banyak, lebih mudah, sama, dan tidak mungkin.

Copyright (C) 2021

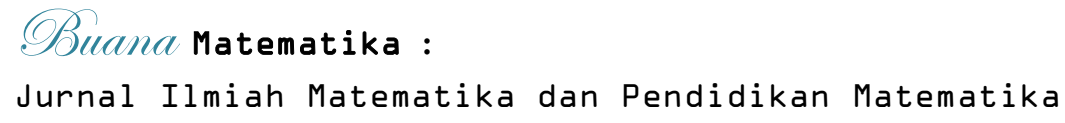




\section{Simpulan}

Pada saat menyelesaikan masalah ruang sampel, siswa cenderung memberikan penjelasan atas jawabannya dengan menggunakan estimasi subjektif dan berdasar keyakinan pengalaman sehari-hari, mengalami kesulitan bahasa serta mendaftar sebagian ruang sampel, sehingga respon yang diberikan siswa termasuk respons non statistis. Pada saat menyelesaikan masalah probabilitas suatu kejadian, siswa cenderung menggunakan estimasi peluang, memberikan alasan secara kuantitatif yaitu dengan membandingkan jumlah objek, sehingga respon yang diberikan siswa termasuk respons statistis. Pada saat menyelesaikan masalah perbandingan probabilitas, siswa cenderung menggunakan estimasi subjektif, memberikan alasan secara kuantitatif yaitu dengan membandingkan jumlah objek antar tempat namun tidak memerhatikan jumlah objek lain, sehingga respon yang diberikan siswa merupakan respons non statistis. Represetasi yang digunakan untuk menjawab masalah adalah menggunakan istilah verbal yang berhubungan dengan kadang-kadang, lebih banyak dan paling banyak, lebih sedikit, dan lebih mudah serta menggunakan angka untuk menunjukkan jawaban.

Berdasarkan hasil penelitian, dapat diketahui bahwa siswa dengan kemampuan matematika rendah tetap dapat memberikan respon terhadap masalah probabilitas. Hanya saja terdapat beberapa kendala, yaitu mengalami kesulitan bahasa dalam memahami soal dan kurang memerhatikan informasi awal. Hal ini sesuai dengan penelitian (Susanti, 2016), bahwa dalam menyelesaikan soal, siswa dengan kemampuan rendah kesulitan menggunakan bahasa sendiri. Seorang guru dapat meningkatkan literasi siswa, yaitu kemampuan membaca dan menulis melalui berbagai metode atau model. Penggunaan model Ishikawa Fishbone dapat membantu siswa memahami isi suatu bacaan dengan baik dan benar (Ariyani \& Prima, 2019).

Pendidikan usia dini sangat penting bagi perkembangan anak. Melalui program pembiasaan sejak dini dapat membentuk karakter mandiri bagi anak, sehingga anak memiliki kemampuan untuk menyelesaikan tugas-tugas perkembangannya (Wiyani, 2020). Penelitian lain menunjukkan bahwa dengan pembelajaran kreatif dapat menghasilkan anak-anak yang cerdas dan kreatif, yaitu anak yang mampu menyelesaikan permasalahan dengan ilmu pengetahuan, serta mampu merealisasikan ide dan gagasannya (Kurniawan, 2015). Oleh sebab itu peran guru sangat penting dalam mengembangkan kreativitas anak melalui modifikasi kurikulum dengan

Copyright $@ 2021$

Buana Matematika :

Jurnal Ilmiah Matematika dan Pendidikan Matematika 
memerhatikan azas-azas berdiferensiasi (Kau, 2017). Selain guru, peran dari keluarga dan sekolah juga tidak kalah penting. Pendidikan ayah dan pendapat ibu dalam berinteraksi dengan anak saat bermain dapat meningkatkan kreativitas (Novita \& Budiman, 2015). Dalam lingkungan sekolah produk kreatifitas guru akan merangsang kreatifitas siswa. Sebagai kepala sekolah untuk meningkatkan kreativitas guru dalam pembelajaran bisa melalui supervisi, pembinaan dan pengembangan, pemberian penghargaan, memagangkan guru, melakukan studi kasus, menciptakan suasana kerja yang menyenangkan dan kebebasan (Oktavia, 2020).

Penelitian ini terbatas hanya pada penggolongan siswa berdasar tingkat kemampuan, utamanya kemampuan tingkat rendah. Banyak faktor lain yang bisa disandingkan dengan kemampuan, misal dari perbedaan jenis kelamin maupun letak demografi. Untuk penelitian yang akan datang diharapkan dapat menggali lebih dalam mengenai perbedaan jenis kelamin dan tempat tinggal dari subjek penelitian sehingga diperoleh informasi yang lebih bervariatif.

\section{Daftar Pustaka}

Ariyani, D., \& Prima, E. (2019). Peningkatan Kemampuan Literasi Siswa Melalui Model Diagram Ishikawa Fishbone di SD Negeri 7 Ciamis. In Seminar Internasional Riksa Bahasa.

Feldman, D. H. (2004). Piaget's stages: the unfinished symphony of cognitive development. New Ideas in Psychology, 22(3), 175-231. https://doi.org/10.1016/j.newideapsych.2004.11.005

Ivayana Sari, D. (2015a). Profil Berpikir Probabilistik Siswa Sekolah Dasar (SD) Berkemampuan Matematika Rendah Dalam Menyelesaikan Tugas Probabilitas. Media Penelitian Pendidikan: Jurnal Penelitian Dalam Bidang Pendidikan Dan Pengajaran, 9(2).

Ivayana Sari, D. (2015b). Profil Berpikir Probabilistik Siswa Sekolah Dasar

(SD) Berkemampuan Matematika Tinggi Dalam Menyelesaikan Tugas Probabilitas. In Prosiding Seminar Nasional Matematika Dan Pendidikan Matematika UNY, 1123-1130.

Jan, I., \& Amit, M. (2009). A Four Phase Model for Predicting the Probabilistic Situation of Compound Events. In HTW Dresden. HTW

Copyright $@ 2021$

Buana Matematika :

Jurnal Ilmiah Matematika dan Pendidikan Matematika 
Dresden.

Kau, M. A. (2017). Peran Guru dalam Mengembangkan Kreativitas Anak Sekolah Dasar. Proceeding Seminar Dan Lokakarya Nasional Bimbingan Dan Konseling 2017, 1(0), 157-166.

Kurniasih, R., \& Sujadi, I. (2017). Probabilistic Learning in Junior High School: Investigation of Student Probabilistic Thinking Levels. Journal of Physics: Conference Series, 895(1), 12028. https://doi.org/10.1088/1742$6596 / 895 / 1 / 012028$

Kurniawan, H. (2015). Pembelajaran Kreatif Untuk Mewujudkan Anak-Anak Yang Cerdas, Kreatif, dan Berkarakter. INSANIA: Jurnal Pemikiran Alternatif Kependidikan, 20(2), 205-216. https://doi.org/10.24090/INSANIA.V20I2.1433

Maher, C. A., \& Ahluwalia, A. (2014). Counting as a Foundation for Learning to Reason About Probability. In: Chernoff E., Sriraman B. (Eds) Probabilistic Thinking. Advances in Mathematics Education. Springer, Dordrecht., 559580. https://doi.org/10.1007/978-94-007-7155-0_30

Novita, D., \& Budiman, M. H. (2015). Pengaruh Pola Pengasuhan Orangtua dan Proses Pembelajaran di Sekolah Terhadap Tingkat Kreativitas Anak Prasekolah (4-5 Tahun). Jurnal Pendidikan, 16(2), 100-109. https://doi.org/10.33830/jp.v16i2.338.2015

Nugrahani, F., \& Hum, M. (2014). Metode Penelitian Kualitatif. In Solo: Cakra Books. Solo: Cakra Books.

Oktavia, Y. (2020). Usaha Kepala Sekolah dalam Meningkatkan Kreativitas Guru dalam Pembelajaran di Sekolah Dasar. In Jurnal Bahana Manajemen $\begin{array}{llll}\text { Pendidikan (Vol. } & \text { 2). } & \text { Retrieved }\end{array}$ http://ejournal.unp.ac.id/index.php/bahana/article/view/3828

Ortiz, J. J., Cañizares, M. J., Batanero, C., \& Serrano, L. (2002). An Experimental Study of Probabilistic Language in Secondary School Textbooks. In In contributed paper to the International Conference On Teaching Statistics (Vol. 6).

Raco, J. (2018). Metode Penelitian Kualitatif: jenis, karakteristik dan keunggulannya. Retrieved from https://osf.io/preprints/mfzuj/

Copyright $@ 2021$

Buana Matematika :

Jurnal Ilmiah Matematika dan Pendidikan Matematika 
Sari, D. I., Budayasa, I. K., \& Juniati, D. (2017). The analysis of probability task completion; Taxonomy of probabilistic thinking-based across gender in elementary school students. AIP Conference Proceedings, 1868. https://doi.org/10.1063/1.4995131

Sari, D. I., Budayasa, I. K., \& Juniati, D. (2018a). Analisis Penyelesaian Tugas Probabilitas Sisanalisis Penyelesaian Tugas Probabilitas Siswa SD Ditinjau dari Perbedaan Kemampuan Matematika dan Gender. AKSIOMA: Jurnal Program Studi Pendidikan Matematika, 7(1), 124. https://doi.org/10.24127/ajpm.v7i1.1344

Sari, D. I., Budayasa, I. K., \& Juniati, D. (2018b). Perkembangan Berpikir

Probabilistik Siswa Sekolah Dasar. Jurnal Riset Pendidikan Dan Inovasi Pembelajaran Matematika (JRPIPM), 1(1), 30. https://doi.org/10.26740/jrpipm.v1n1.p30-39

Sharma, S. (2012). Cultural Influences in Probabilistic Thinking. Journal of Mathematics Research, 4(5). https://doi.org/10.5539/jmr.v4n5p63

Sharma, S. (2014). Cultural Influences in Probabilistic Thinking. Advances in Mathematics Education. Springer, Dordrecht, 657-681. https://doi.org/10.1007/978-94-007-7155-0_35

Sugiyono. (2013). Metode Penelitian Kuantitatif, Kualitatif, dan R\&D. In Bandung: Alfabeta.

Sujadi, I., Kurniasih, R., \& Subanti, S. (2017). The Effectiveness of Learning Material with Edmodo to Enhance The Level of Student's Probabilistic Thinking. AIP Conference Proceedings, 1848, 40014. https://doi.org/10.1063/1.4983943

Susanti, D. (2016). Profil Berpikir Kreatif dalam Menyelesaikan Soal Cerita Matematika. Jurnal Buana Matematika, 6(2), 11-16. Retrieved from http://jurnal.unipasby.ac.id/index.php/buana_matematika/article/view/3 $64 / 229$

Way, J. (2003). The Development of Young Children's Notions of Probability. In In Proceedings of CERME (Vol. 3, pp. 1-8).

Wiyani, N. A. (2020). Manajemen Program Pembiasaan bagi Anak di PAUD Copyright $(02021$

Buana Matematika :

Jurnal Ilmiah Matematika dan Pendidikan Matematika 
Banyu Belik Purwokerto. ThufuLA: Jurnal Inovasi Pendidikan Guru Raudhatul Athfal, 8(1), 029-042. https://doi.org/10.21043/thufula.v8i1.7044

\section{Riwayat Hidup Penulis}

\section{Rahmawati Nur Aini}

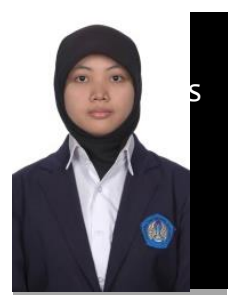

Lahir di Situbondo, 16 Desember 1991. Tutor di UPBJJ Universitas Terbuka Surabaya. S1 Pendidikan Matematika Universitas Negeri Surabaya, Surabaya, lulus tahun 2014; S2 Pendidikan Matematika Universias Surabaya, Surabaya, lulus tahun 2016. Analisis pemahaman siswa SMP dalam menyelesaikan masalah aljabar pada PISA.

\section{Dwi Juniati}

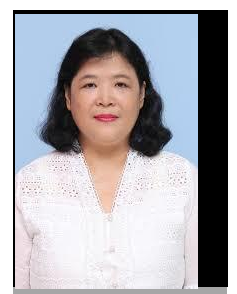

Lahir di Malang, 15 Juni 1967. Dosen Pendidikan Matematika Universitas Negeri Surabaya. S1 Pendidikan Matematika IKIP Negeri Malang, Malang, lulus tahun 1990; S2 Matematika Institut Tekknologi Bandung, Bandung, lulus tahun 1995. S3 Matematika (Topologi) Universite' de Provence, MarseillePerancis, lulus tahun 2002. Profile of student's quantitative reasoning in solving problems based on the cognitive style field independent and field dependent (Math Didactic: Jurnal Pendidikan Matematika 6 (3), 244-254).

\section{Pradnyo Wijayanti}

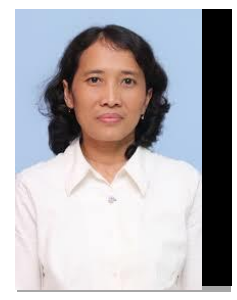

Lahir di Kediri, 09 April 1969. Dosen Pendidikan Matematika Universitas Negeri Surabaya. S1 Pendidikan Matematika IKIP Yogyakarta, Yogyakarta, lulus tahun 1993; S2 Pendidikan Matematika Universitas Negeri Surabaya, Surabaya, lulus tahun 2000. S3 Pendidikan Matematika Universitas Negeri Surabaya, Surabaya, lulus tahun 2013. Creativity of Secondary Mathematics Teacher within Solve the2-Dimentional Figure Problem Based On Teaching Experiences. IOP Conf. Series: Journal of Physics: Conf. Series 1108 (2018) 012042 doi :10.1088/1742-6596/1108/1/012042 
Jurnal Ilmiah Matematika dan Pendidikan Matematika Vol. 11 No. 1 (2021)

Copyright $@ 2021$

Buana Matematika :

Jurnal Ilmiah Matematika dan Pendidikan Matematika 